\title{
Developing Teaching Material on Report Text of Observation Results Concerning Green Industry as Scientific Awareness for Senior High School Students
}

\author{
Ahmad Syukron'1, Arju Mutiah ${ }^{2}$ \\ ${ }^{1}$ Faculty of Education and Teacher Training, Jember University \\ Email: ahmadsyukron@unej.ac.id \\ ${ }^{2}$ Faculty of Education and Teacher Training, Jember University \\ Email: arju.fkip@unej.ac.id
}

\begin{abstract}
Lately, energy sustainability has become an acutely disputed issue, both at national and global scale. To keep up with the phenomenon, students need to accrue their scientific awareness to innovate in the Green Industry corridor. This research is a development research applying a 4D model (Defining, Designing, Developing, and Disseminating). Based on expert validation and empirical validation, the applicability of the teaching materials under development was $92 \%$. On the other hand, based on the calculated results of the results of product tryouts, the applicability was found to reach $91 \%$. The effectiveness, as found in test using Paired Sample T-Test, generated the value of $t=12.465$ with a significance level of 0.000 ( $p<0.05)$, corroborated with a mean difference of 3.0625. The posttest mean was 84.7188 with SD 2.96468, while the pretest mean was 81.6563 with SD 3.16849.
\end{abstract}

Keywords- Teaching material, Report Text of Observation Results, Green Industry, Scientific Awareness.

\section{INTRODUCTION}

Lately, energy has become a topic of recent discussion, both in national and global scale. This is closely related to the availability of energy sources in the world, coupled with the problem of global warming and climate change. The energy development axis is a priority in most political agenda acros s various countries in the world. It is estimated that global energy demand will double by 2050 (Hendratno, 2014). This condition drives every country to strive to increase the acceleration and innovation in the energy sector.

In Indonesia, the government has planned and implemented several strategic policies nationally to maintain national energy stability. This is important, considering the population growth and national economic growth. Energy consumption in Indonesia in a decade continues to increase by around 7-8\% per year (Ministry of Energy and Mineral Resources, 2012). The government has made various efforts to overcome this issue, such as converting oil to gas energy, reducing oil subsidies, developing wind power plants, and even developing the electric car industry in Indonesia.

Saving energy is bound to the policy named green energy. Environmentally friendly energy is important to be developed, given the fact that increasingly limited natural resources, energy crisis, and weaker carrying capacity of the environment have worsened for the last few years. The concept of green energy is the starting point for the development of an environmentally friendly industry or better known as the Green Industry. Green Industry is an industry concept that emphasizes on pollution-free, saving energy, preserving natural resources, and economical and safe value for employees, community and customers (Kemenprin, 2012). This is indicated by the race of producers who label their products with "Save Energy" and "Ecolable".

In this context, education plays an important role in continuing to prepare human resources (HR) to build Green Industry in national scale in Indonesia, even in the global context. Learning material concerned with Green Industry needs to be given emphas is at each education unit, especially in high school. This is the case because the curriculum has explained that the scope of high school interaction is within the reach of world association.

To support this, students need to establish their scientific awareness to be able to innovate in the Green Industry corridor. There are two main terms within this regard, namely Scientific and Awareness. Terminologically, scientific comes from the word "science". Strictly speaking, scientific are things related to scientific 
characteristics. On the other hand, "awareness" refers to attitudes that are embedded in human mentality. Strictly speaking, Scientific awareness is an attitude in the form of awareness to think scientifically.

The theme of Green Industry for accruing Scientific Awareness of high schoolstudents can be internalized into teaching materials (textbooks) used in learning activities. Teaching materials in the form of textbooks are practical learning instrument because they present material in the form of learning units. In principle, textbooks are prepared to meet students' learning needs which are packaged in specific or systematic units or activities based on the curriculum (Lestari, 2013:2-3). The practicality of the textbook also lies in the presentation of material that has been designed according to the context of teaching and learning activities in the classroom. Text books always present a variety of exercise for each basic competency that students have to master. This certainly helps students to understand every material demanded by the curriculum, both structured in class and for independent study at home. Bahasa Indonesia is the right medium for presenting content-based learning because it is text-based learning in nature. In text-based learning, students are invited to understand various ways of presenting ideas in various types of texts, and then learn them further in a variety of language activities. This is in line with the practice of using Indonesian in daily life that covers a variety of goals and situations (Mutiah, 2014:215). Bahasa Indonesia presents material in the form of texts that can be filled with Green Industry content.

The text pertinent to observation report is the right material to present Green Industry content. The text of the observation report is classified as factual text that is scientific. Factual text is text presenting information or ideas that aim to describe, tell, or convince readers or listeners (Anderson and Kathy, 2003:3).

As a reference for developing teaching text material for observational reports with the theme of the Green Industry, as well as the endeavorto scaffold the students' Scientific Awareness, a study was conducted on $10^{\text {th }}$ grade Indonesian textbooks prepared by the Ministry of Education and Culture. This book is consistently compiled with a 4-stage pattern, namely: (1) building context, (2) text modeling, (3) composing text (groups), and (4) composing text independently. In the text for observation report, there are several parts that need to be corrected. Basic Competence 3.1 requires the students to understand the text of the observation report which has been described through an understanding of the concept/characteristics of the text, but the presentation is too deductive. This does not encourage the students to construct their knowledge independently. At the stage of producing text, the exercises presented should be able to become steps that guide students to master the text. However, the exercises presented still do not show the integrity of the process of producing report text.

From various reviews aforementioned, several things can be formulated as the foundation for developing the teaching material of the observation report text with the theme of Green Industry as Scientific Awareness catalyst for high school students. First, Green Industry is an apt concept to overcome energy problems nationally and globally. To prepare human resources who are able to innovate in Green Industry, learning activities need to form students' scientific attitude (Scientific Awareness). Second, the textbooks published by the Ministry of Education and Culture for 10th grade high school still require some development, especially in the observation report text material. The text of observation report belongs to scientific factual text. Therefore, integrating Green Industry into learning observation report text is indeed the right option for forming senior high school students' scientific awareness.

This research and development study aims to produce the teaching materials for observation report text concerned with Green Industry as a form of Scientific Awareness catalyst for senior high school students, which satisfy (1) validity and (2) effectiveness criteria. Validity is assessed in terms of substance/content/content of materials, arrangement and graphics of instructional materials, and content of Green Industry as a form of Scientific Awareness. The validity of the substance/content includes the accuracy of the theory, the completeness of the material, the depth of the material, and aspects of learning. Systematic validity and graphics include organization, language, and graphics. The validity of the Green Industry includes the accuracy of the theory/concept of Green Industry as means for forming Scientific Awareness, the authenticity of the Green Industry as a means for scaffolding Scientific Awareness, the usefulness and attractiveness of teaching materials, and the varieties of contents concerned with Green Industry as a means for forming Scientific Awareness presented.

\section{RESEARCH METHODS}

This research and development applied a four-D Model (4D) development model from Thiagarajan, Dorothy, and Melvyn. Thiagarajan et al. (1974:5-9) explain that the model consists of 4 stages, namely: Defining (designation), Designing (design), Developing (development), and Dis seminating (distribution).

The product validation and tryout phase aimed to improve the quality of teaching material products. In this research and development, validation was carried out by the 
validator, while the tryout was carried out by the targeted subjects of product development. The validator group consisted of expert validators and practitioner validators. Expert validators were experts in the field of learning Bahas Indonesia and literature as well as experts in Green Industry, while practitioner validators were Bahasa Indonesia subject teachers at SMAN4 Jember. Meanwhile, the test subjects were 10th grade students of high school at SMAN 4 Jember.

The instruments of data collection used to obtain data in this research and development included the main instruments and supporting instruments. (1) The main instrument was the prototype of the teaching material of the observation report text regarding Green Industry as the catalyst of Scientific Awareness for high school students. Another main instrument was lesson plan which also had a scoring rubric (profile) for composing observation report text. (2) Supporting instruments included questionnaires and interview guidelines. The interview guide was used to interview the teacherduring the needs analys is phase. The questionnaire instrument consisted of four models, namely: (a) questionnaire for needs analysis, (b) expert validation questionnaire, (c) practitioner validation questionnaire, and (c) assessment questionnaire for product testing (students). The spread of the use of data collection instruments in this research and development were as follows.

Data analysis for verbal data obtained from interview and written comments in the validation questionnaire was carried out by recording points from the results of interview activities and comments contained in the questionnaire. After that, evaluation on the important points was carried out, which served as a reference for product revision. Furthermore, for numeral data quantitative analysis was used on data obtained from expert validation questionnaires, practitioner validation questionnaires, and tryout questionnaires, as well as product effectiveness test. Therefore, there were three analysis models for numeral data in this research and development, namely analysis for quantification analysis of validation and tryout questionnaires, and analysis of product effectiveness. Furthermore, the data obtained from the questionnaire (validation and tryout) were analyzed by the formula and conversion of 4-scale evaluation by Arikunto (1996:244) as shown in the following formula and table.

a) The formula for analyzing each item

$\mathrm{P} i=\frac{x}{x i} \times 100 \%$

Description:

$\mathrm{P} i=$ percentage of item appropriateness $x=$ response on each item

$x \mathrm{i}=$ maximum $\mathrm{mcore}$ on each item

b) The formula for analyzing all items

$\mathrm{P}=\frac{\sum x}{\sum x i} \times 100 \%$

Description:

$\mathrm{P} \quad=$ Percentage of product appropriateness

$\sum x=$ the total responses on all items

$\sum x i=$ the total maximum scores for all items

The percentage of the whole set of items is then interpreted, using the following classification.

Table 1 Analysis and Product Qualification

\begin{tabular}{ccc}
\hline Percentage & Qualification & Folow-up \\
\hline $85 \%-100 \%$ & Very appropriate & Implementation \\
\hline $75 \%-84 \%$ & Appropriate & Implementation \\
\hline $55 \%-74 \%$ & Fairly appropriate & Revision \\
\hline$<55 \%$ & Hardly appropriate & Change \\
\hline
\end{tabular}

Information :

(1) In the percentage range of $85 \%-100 \%$, the teaching materials are classified as being very appropriate and thus ready for actual implementation.

(2) In the percentage range of $75 \%<85 \%$, the teaching materials are classified as being appropriate and thus ready for actual implementation

(3) In the percentage range of $55 \%<75 \%$, the teaching materials are classified as fairly appropriate and thus in need of revision prior to actual implementation.

(4) In the percentage range of $<55 \%$, the teaching materials are classified as being hardly appropriate and thus in need of substitution.

\section{2) Analisis of Product Effectiveness}

The product effectiveness was investigated using the prepost experiment on a single group. Hereunder is the scheme of experiment.

\section{$\mathrm{O} 1 \mathrm{X} \quad \mathrm{O} 2$}

Description

O1 : pre-test

$\mathrm{X}$ : the instruction of composing report text of observation using the product developed

$\mathrm{O} 2$ : post-test

The data of product effectiveness was analyzed statistically using t Paired Sample T-test as the data was normally distributed. The data distribution was analyzed using Onesample Kolmogorov-Smirnov test. This was done using SPSS 22 for Windows. 


\section{RESULTS AND DISCUSSION}

\section{1 . Product Description}

This product of research and development is an instructional text material focusing on Green Industry for high school in the form of a textbook. This teaching material is a book printed with dimensions of $21 \mathrm{~cm} \times 29.7$ $\mathrm{cm}$. The software used to compile the formulations of teaching materials is Microsoft Word 2010 and Corel Draw12.

The systematic presentation of teaching materials is divided into three parts, namely the initial part, the core section, and the final part. The initial section consists of the front cover, copyright page, introduction, instructions for presenting the contents of the book, table of contents, opening unit, and concept map. The core section contains material from Core Competence 3 (understanding) and Core Competence 4 (skills) in the text material of the observation report. The final section contains reference, author history, and back cover.

\section{Product Validation and Tryout}

Data from the validation and tryout results in this research and development study were divided into two types, namely verbal data and numerical data. Verbal data in this study were the comments from expert validators, practitioners, and students in the questionnaire. Meanwhile, numeral data was obtained from the quantification of the responses of expert validators, practitioners, and students' responses in the questionnaire. The validator group consisted of expert validators and practitioners, while the subject of this research and development tryout was senior high schoolstudents. There were 1 expert validator and 1 practitioner validator in this study. The tryout was conducted at the XIPA X class at SMAN 4 Jember. Hereunder is the list of validators involved in the study.

Table 2 Identity and Code of Validator

\begin{tabular}{clll}
\hline No & $\begin{array}{c}\text { Validator } \\
\text { Qualification }\end{array}$ & \multicolumn{1}{c}{ Name } & Code \\
\hline 1 & Expert & Nurul Azizah, S.Pd., & VA \\
& validator & M.Pd. & \\
\hline 2 & Practice & $\begin{array}{l}\text { Sofiyatul Annisa, } \\
\text { validator }\end{array}$ & VP.Pd. \\
\end{tabular}

\subsection{Verbal Data}

Verbal data in the form of notes, comments, criticisms, and suggestions were tabulated and mapped to facilitate revision of the product. This was adjusted to the assessment aspects contained in the validation questionnaire. The following is a verbal data presentation obtained.
Table 3 Verbal data of Validator

\begin{tabular}{|c|c|c|c|}
\hline No & $\begin{array}{l}\text { Evaluation } \\
\text { Aspects }\end{array}$ & Verbal Data & Code \\
\hline 1. & Organization & $\begin{array}{l}\text { In the Table of Content, } \\
\text { there is mis spelling. }\end{array}$ & VP \\
\hline 2. & Language & Please check the preface & VA \\
\hline 3. & $\begin{array}{l}\text { Theory } \\
\text { Accuracy }\end{array}$ & The material is incomplete & VA \\
\hline \multirow{2}{*}{4.} & \multirow{2}{*}{$\begin{array}{l}\text { Material } \\
\text { Coverage }\end{array}$} & $\begin{array}{l}\text { Please check Unit } 4, \\
\text { especially activity } 1 \text { and } 2\end{array}$ & VA \\
\hline & & $\begin{array}{l}\text { The structure of observation } \\
\text { report text needs revising }\end{array}$ & $\mathrm{VP}$ \\
\hline 5. & $\begin{array}{l}\text { Material } \\
\text { depth }\end{array}$ & $\begin{array}{l}\text { There are some more } \\
\text { materials required, including } \\
\text { definition and editing. }\end{array}$ & VA \\
\hline 6. & $\begin{array}{l}\text { Instruction } \\
\text { aspect }\end{array}$ & $\begin{array}{l}\text { The authors may include } \\
\text { topics to stimulate students' } \\
\text { writing. } \\
\text { Every material needs to be } \\
\text { presented in each } \\
\text { practice/exercise so students } \\
\text { can be encouraged to } \\
\text { integrate more concepts }\end{array}$ & VA \\
\hline
\end{tabular}

2.2 Numerical Data

Validation and product tryout also generated numerical data. The validation was done by two validators, including expert validator and empirical validator. This validation produced numerical data which demonstrated the quantification of questionnaires. Hereunder is the results of validation.

2.2.1 Expert Validation and Empirical Validation

Hereunder is the results of validation.

Table 4 Validation Results of Teaching Expert

\begin{tabular}{|c|c|c|c|c|c|c|}
\hline \multirow{2}{*}{ No } & \multirow{2}{*}{$\begin{array}{c}\text { Evaluation } \\
\text { Aspects }\end{array}$} & \multicolumn{2}{|c|}{ Validator } & \multirow{2}{*}{$x$} & \multirow{2}{*}{$X i$} & \multirow{2}{*}{$\mathbf{P i}$} \\
\hline & & VA & VP & & & \\
\hline 1 & $\begin{array}{l}\text { Theory } \\
\text { accuracy }\end{array}$ & 7 & 8 & 15 & 16 & $94 \%$ \\
\hline 2 & $\begin{array}{l}\text { Material } \\
\text { coverage }\end{array}$ & 6 & 8 & 14 & 16 & $88 \%$ \\
\hline 3 & Material depth & 7 & 12 & 19 & 24 & $79 \%$ \\
\hline 4 & $\begin{array}{l}\text { Instruction } \\
\text { aspect }\end{array}$ & 15 & 16 & 31 & 32 & $97 \%$ \\
\hline 5 & Organization & 11 & 12 & 23 & 24 & $96 \%$ \\
\hline 6 & $\begin{array}{l}\text { Language } \\
\text { aspect }\end{array}$ & 7 & 8 & 15 & 16 & $94 \%$ \\
\hline 7 & Graphics & 32 & 35 & 67 & 72 & 93\% \\
\hline \multicolumn{4}{|c|}{ Total score $(\Sigma)$} & 184 & 200 & $92 \%$ \\
\hline
\end{tabular}


Based on data from expert learning validation, the number of expert validator answers and practitioner validators per item $\left(\sum x\right)$ is 184 , while the maximum score is 200 . The relationship between the two aspects serves to determine the percentage of eligibility (P). The percentage of eligibility is determined by the following calculation.

$$
\begin{aligned}
\mathrm{P} & =\sum \mathrm{x} / \sum \mathrm{xi} \text { X 100\% } \\
& =184 / 200 \times 100 \% \\
& =92 \%
\end{aligned}
$$

Based on the results of calculations against expert validation and practitioner validators, the appropriateness percentage of teaching materials was $92 \%$. In accordance with predetermined criteria, the resultant percentage indicates that the qualification of teaching materials is classified as feasible from the expert point of view and empirical validators' opinion. This is in accordance with the opinion of Arikunto (1996:244) which points out that valid teaching material is eligible for follow-up implementation if it reaches a percentage of $76 \%-100 \%$.

\subsubsection{Product Testing}

The product tryout was carried out in class $\mathrm{X}$ of Mathematics and Natural Sciences 3 of SMAN 4 Jember. The product tryout was conducted in the form of activities to fill out questionnaire. There were 32 students who participated in the product tryout. The following is a recap of the numeral data from the product tryout.

\section{Table 5 Tryout Results}

\begin{tabular}{clccc}
\hline No & Evaluation Aspects & $\mathbf{x}$ & $\mathbf{X i}$ & $\mathbf{P i}$ \\
\hline 1 & Content & 348 & 384 & $\mathbf{9 1 \%}$ \\
\hline 2 & Language & 236 & 256 & $\mathbf{9 1 \%}$ \\
\hline 3 & Arrangement & 234 & 256 & $\mathbf{9 2 \%}$ \\
\hline 4 & Presentation & 468 & 512 & $\mathbf{9 1 \%}$ \\
\hline & Total Score $\left(\sum\right)$ & $\mathbf{1 2 8 6}$ & $\mathbf{1 4 0 8}$ & $\mathbf{9 1 \%}$
\end{tabular}

Based on the calculated results of the results of product tryouts, the appropriateness percentage of the teaching materials is found to be $91 \%$. In accordance with predetermined criteria, the percentage indicates that the qualifications of teaching materials are classified as very appropriate from the point of view of users of instructional materials or class $\mathrm{X}$ high school students. This is in accordance with the opinion of Arikunto (1996: 244) which reveals valid teaching material with follow-up without revision if it reaches a percentage of $76 \%-100 \%$.

\section{Product Effectiveness Test}

Effectiveness test of the product was conducted by referring to the Basic Competencies 3.1, which is concerned with understanding the Observation Report Text. This test focused on the students' scores obtained at the same Basic Competence when they had not used the report text teaching material under development.

The first step in product effectiveness testing was the data normality test using the One-Sample KolmogorovSmirnov Test. The results aimed to determine the different test techniques used. The following is the results of the normality test of the pretest and posttest data on Basic Competence 3.1 , that is understanding the text of the

\begin{tabular}{|c|c|c|c|}
\hline \multicolumn{4}{|c|}{ One-Sample Kolmogorov-Smirnov Test } \\
\hline & & $\begin{array}{c}\text { Pretes } \\
\text { (KD 3.1) }\end{array}$ & $\begin{array}{l}\text { Postes } \\
\text { (KD 3.1) }\end{array}$ \\
\hline \multicolumn{2}{|l|}{$\mathrm{N}$} & 32 & 32 \\
\hline \multirow{2}{*}{$\begin{array}{l}\text { Normal } \\
\text { Parameters } a, b\end{array}$} & Mean & 81.6563 & 84.7188 \\
\hline & Std. Deviation & 3.16849 & 2.96468 \\
\hline \multirow{3}{*}{$\begin{array}{l}\text { Most Extreme } \\
\text { Differences }\end{array}$} & Absolute & .168 & .212 \\
\hline & Positive & .113 & .212 \\
\hline & Negative & -.168 & -.123 \\
\hline \multicolumn{2}{|c|}{ Kolmogorov-Smirnov Z } & .950 & 1.200 \\
\hline \multicolumn{2}{|c|}{ Asymp. Sig. (2-tailed) } & .327 & .112 \\
\hline \multicolumn{4}{|c|}{ a. Test distribution is Normal. } \\
\hline \multicolumn{4}{|c|}{ b. Calculated from data. } \\
\hline
\end{tabular}
observation report.

Table 6 Normality Test Results

\begin{tabular}{|c|c|c|c|c|}
\hline \multicolumn{5}{|c|}{ Paired Samples Statistics } \\
\hline & Mean & $\mathrm{N}$ & $\begin{array}{c}\text { Std. } \\
\text { Deviation }\end{array}$ & $\begin{array}{l}\text { Std. Error } \\
\text { Mean }\end{array}$ \\
\hline $\begin{array}{ll}\text { Pair } & \text { PRETES } \\
1 & (\text { KD 3.1) }\end{array}$ & 81.6563 & 32 & 3.16849 & .56011 \\
\hline $\begin{array}{l}\text { POSTES } \\
(\mathrm{KD} 3.1)\end{array}$ & 84.7188 & 32 & 2.96468 & .52409 \\
\hline
\end{tabular}

\begin{tabular}{|c|c|c|c|}
\hline \multicolumn{4}{|c|}{ Paired Samples Test } \\
\hline \multicolumn{4}{|c|}{ POSTES (KD 3.1) - PRETES (KD 3.1) } \\
\hline \multirow{5}{*}{$\begin{array}{l}\text { Paired } \\
\text { Differences }\end{array}$} & \multicolumn{2}{|l|}{ Mean } & 3.06250 \\
\hline & \multicolumn{2}{|l|}{ Std. Deviation } & 1.38977 \\
\hline & \multicolumn{2}{|l|}{ Std. Error Mean } & .24568 \\
\hline & \multirow{2}{*}{$\begin{array}{l}95 \% \text { Confidence } \\
\text { Interval of the } \\
\text { Difference }\end{array}$} & Lower & 3.56356 \\
\hline & & Upper & 2.56144 \\
\hline & \multicolumn{2}{|l|}{$\mathrm{t}$} & 12.465 \\
\hline & \multicolumn{2}{|l|}{ df } & 31 \\
\hline & \multicolumn{2}{|l|}{ Sig. (2-tailed) } & .000 \\
\hline
\end{tabular}

Table 7 The Results of Paired Sample Test

Based on the table of results of the normality test, it is clear that all pretest and posttest data in Basic Competence 3.1 
demonstrate normal distribution. That is, the effectiveness test can use the Paired Sample T-Test. The test was amde operative also because the data used was a pair of data owned by the subject, namely the score of the pretest and the result of the posttest. The results of different tests on student grades on Basic Competence 3.1 can be seen in the following table.

From the results of statistical tests of different abilities, understanding the text of the observation report before and after the treatment generated $t$ value of 12.465 with a significance level of 0.000 ( $\mathrm{p}<0.05)$. The value of $t$ (positive) shows that the posttest mean is greater than that of pretest mean with the mean difference of 3.0625. The posttest mean is 84.7188 with SD 2.96468, while the pretest mean is 81.6563 with SD 3.16849. It can be concluded that there is a significant difference between the value of understanding the observation report text before and after treatment, as shown by $\mathrm{p}<0.05$. That is, there is an increase in the score corresponding to students' understanding on the observation report text after using the developed teaching material.

\section{CONCLUSION}

The observation report text instructional material concerning Green Industry for Senior High School was developed from 4 Basic Competencies (Basic Competence 3 and 4). Teaching materials present the material of the report text as a whole in the form of learning units, including: Unit 1. Identifying the Characteristics of Report Text on Observation Results, Unit 2. Interpreting the Contents of the Report Text on Observation Results, Units 3. Analyzing the Linguistic Aspects of the Report Texts on Observation Results, Unit 4. Composing Report Text on Observation Results, and Achievement Tests.

Each unit presents activities that contain learning activities to master basic competencies. These learning activities lead students to master the material through a series of processes. The learning activities presented do not expose material that is theoretically direct. However, the material is presented in Discovery Learning method, so students learn to find and understand material through a process. Furthermore, the mastery of learning material will be improved through the exercises presented in the teaching material. Exercises in the form of questions related to the material taught will train students to complete the practices in each unit. At the end of learning, there is an achievement test that contains the core sections of the book coupled with a achievement test that contains questions about eight materials that have been studied.

Based on the description above, it can be concluded that the four learning units developed in teaching materials are a unified whole. The four learning units are the unity that has been designed with respect to the 2013 Curriculum, Bahasa Indonesia subjects at the eleventh grade of high school to master the text material of the observation report text which includes: the ability to understand, interpret, analyze, compose the report text of observation.

Teaching material for the report text of observation is developed by focusing on Green Industry. Green Industry, which serves the thematic focus of textbook development, is embedded in every aspect of teaching materials. There are three main things in teaching materials that reflect the Green Industry, which comprise of text, learning activities, and illustrations. The integration of the Green Industry into teaching materials will foster students'knowledge related to environmentally friendly technological concepts.

The instructional materials developed have the uniqueness of teaching materials that distinguish them from other teaching materials. This teaching material presents learning text reports of observation results in class $\mathrm{X}$ of senior high school. Each stage of learning guides students to master material independently. This aims to avoid the impression of teacher-centered learning, but rather the students are guided to construct their understanding independently. These objectives are accommodated through activities and exercises presented in teaching materials, as well as communicative instructions.

From the description above, it can be concluded that the product of the report text material of observation results with the theme concerning Green Industry for senior high school has a number of distinctions that distinguish it from other similar products. 1) This teaching material presents the learning report text of the results of the observation in class $X$ high school in process-based instruction. 2) This teaching material has completely presented the report text material as a result of full observation, alluding to 4 Basic Competencies. 3) This teaching material focuses on themes related to Green Industry, which can be seen in model texts, learning activities, and illustrations.

\section{REFERENCES}

[1] Anderson, Marh dan Kathy Anderson. 2003. Text Types in English 3. Australia: Macmillan Ecucation Australia PTY LTD.

[2] Arikunto, Suharsimi. 1996. Prosedur Penelitian Suatu Pendekatan Praktek.

[3] Badan Standar Nasional Pendidikan. 2007. Standar Penilaian Buku Teks. Jakarta: BNSP.

[4] Bennett, Amanda, Alice Carter, dan David Marino. 2013. The Genre Handbook for Staff. Australia: Whyalla Secondary Schools.

[5] Coyle, D. 2007. Content and Language Integrated Learning: Towards a Connected Research Agenda for CLIL Pedagogies. The International 
Journal of Bilingual Education and Bilingualism.

10(5), 543-562.

[6] Hendratno, Seto. 2014. Isu Global Energi. http://studioriau.com/el/artikel/energi/isu-globalenergi.html (diakses 4 Juni 2017)

[7] Kemenprin. 2012. Efisiensi dan Efektivitas dalam Implementasi Industri Hijau. Jakarta: Kementrian Perindustrian.

[8] Kementerian Pendidikan dan Kebudayaan. 2015. Bahasa Indonesia Kelas 10 SMA/MA. Jakarta: Kementerian Pendidikan dan Kebudayaan

[9] Kementrian ESDM. 2012. Kajian Analisis Isu-isu Sektor ESDM. Jakarta:Pusat Data dan Informasi Sumber Daya Mineral.

[10] Lestari, Ika. 2013. Pengembangan Bahan Ajar Berbasis Kompetensi. Padang: Akdemia Permata.

[11] Majid, Abdul. 2009. Perencanaan Pembelajaran Mengembangkan Standar Kompetensi Guru. Bandung: PT Remaja Rosdakarya.

[12]Muslich, Masnur. 2008. Textbook Writing. Yogyakarta : Ar-Ruzz Media.

[13] Mutiah, Arju. 2014. Representasi Pendekatan Whole Language dalam Sajian Materi Pembelajaran Bahasa Indonesia Berbasis Teks. Dalam Prosiding Semnas Bahasa, Sastra, dan Pembelajarannya. Yogyakarta: Gress Publishing.

[14] Prastowo, Andi. 2013. Panduan Kreatif Membuat Bahan Ajar Inovatif. Yogyakarta: DIVA Press.

[15] Tarigan, Henry Guntur dan Djago Tarigan. 1990. Telaah Buku Teks Bahasa Indonesia. Bandung: Angkasa.

[16] The National Literacy Strategy. 2003. Year6 Planning Exemplification 2002-2003: Report Writing Unit. United Kingdom:The National Literacy Strategy.

[17] Thiagarajan, Sivasailam, Dorothy S. Semmel, dan Melvyn I. Semmel. 1974. Instructional Development for Training Teacher of Exceptional Children. Minneapolis, Minnesota.

[18] UNIDO. 2011. UNIDO Green Industry. Vienna:United Nations Industrial Development Organization

[19] Viskontas, Indre. 2011. 12 Essential Scientific Concepts. San Fransisco: Universisty of California. 